\title{
Emerging Animal Protein Source to Replace Fish Meal in the Diets of Nile Tilapia (Oreochromis niloticus) Fry
}

\author{
Sanjay Singh Rathore ${ }^{1^{*}}$ and Sajid I. Yusufzai ${ }^{2}$ \\ ${ }^{1}$ Department of Aquaculture, College of Fisheries, Karnataka Veterinary, Animal and \\ Fisheries Sciences University, Mangalore-575002, Karnataka, India \\ ${ }^{2}$ College of Fisheries Science, Junagadh Agricultural University, \\ Veraval - 362265, Gujarat, India \\ *Corresponding author
}

\section{A B S T R A C T}

\section{Keywords}

Feed efficiency, Fish meal, Growth, O. niloticus, Shrimp head meal

Article Info

Accepted:

10 April 2018

Available Online:

10 May 2018

A 60 days feeding trial was performed to assess the potential use of shrimp head meal (SHM) as complete replacement of fish meal (FM) in commercial diets of Nile tilapia (Oreochromis niloticus) fry.Quadruple groups were fed each of five isonitrogenous (40\%) diets were formulated to contain graded levels of SHM at 0\% (control diet, T1), 25\% (T2), $50 \%$ (T3), 75\% (T4) and 100\% (T5), respectively. Total 200 numbers of tilapia fry (mean initial weight $\pm \mathrm{SE}, 1.56 \pm 0.1 \mathrm{~g}$ ) were stocked into $40 \mathrm{~L}$ aquarium tanks $(10$ fish in each tank) and fed experimental diets ad libitum during feeding trial. After 60 days, diet T3 showed significantly $(\mathrm{p}<0.05)$ higher weight gain $(354.84 \pm 3.32)$, protein efficiency ratio $(1.64 \pm 0.02)$ and higher feed efficiency $(65.67 \pm 0.81)$ as compared to control and other treatment diets. Thus, it can be concluded from the study that SHM is a potential protein source and can be used to substitute fish meal up to $50 \%$ in the diets of tilapia ( $O$. niloticus) fry and the optimal level of fish meal replacement with SHM was determined by quadratic regression analysis to be in between 43.83 and $50.29 \%$ on the basis of higher weight gain and maximum protein efficiency ratio.

\section{Introduction}

In aquaculture practices, only the feed accounts more than half of the production cost and protein in the feed is the most important component in the rise of feed cost making a massive proportion of the total operational cost (Gatlin, 2010). Currently, fishmeal is accepted by nutritionists as a superior, palatable and very digestible feed ingredient that is favored for incorporation to the diet of most farm animals, especially fish and shrimp
(Miles and Chapman, 2012). Source of fish meal is the finite and high demand of fishmeal for aqua feeds and other livestock results in growing cost for this product (FAO, 2008). Hence, there is essential to investigate suitable alternatives for future (Hardy and Tacon, 2002). Replacement of fish meal by less expensive protein sources of either animal or plant origin in the fish feed are necessary (Fontainhas-Fernandes et al., 1999). It was reported that a large amount of protein with the excellent amino acid profile is found in 
shrimp head meal. Therefore, shrimp head meal can satisfactorily replace fish meal in aqua-feeds as it will scarce and expensive in near future. However, the level of chitin and ash contents are high in shrimp head meal which limits nutrient availability, utilization and digestibility in fish (Meyers, 1986) mainly in tilapia (Oreochromis niloticus) due to its high acceptability and digestibility of offered feed. Research has successfully assessed many inexpensive sources for different species of tilapia, with varying results.

Hence, it is applicable to highlight the se protein sources for tilapia, with prominence on the sources that have an economic approach and are locally available, particularly in developing countries (El-Sayed, 1999) and shrimp head meal has potential to become one of the best alternative feed for tilapia. The present study was conducted to assess the effects of shrimp head meal on growth performance, feed utilization and survival in tilapia (O. niloticus) fry.

\section{Materials and Methods}

\section{Site of the experiment and experimental} fish

The experiment was performed at the Wet Laboratory of Department of Aquaculture, College of Fisheries Science, JAU, Veraval, Gujarat, India over a period of 60 days. Juvenile Oreochromis niloticus of total length $4.15 \pm 0.03 \mathrm{~cm}$ (mean \pm SE) and weight $1.56 \pm$ $0.10 \mathrm{~g}$ were selected in the experiment. The fish, procured from the Fish Hatchery, Kachchh Vikas Trust, Bhuj, District-Kachchh, Gujarat were brought to the Wet Laboratory at the College of Fisheries Science, JAU, Veraval, Gujarat held in plastic pools (500 L) with continuous aeration for 15 days and the $n$ stocked into the plastic aquarium tanks one week before beginning of the experiment. The experimental set-up comprised of 20 plastic tanks (40 L capacity), with four tanks of fish for each of five treatments. The experimental tanks were cleaned manually and siphoned every day to remove fecal matter. Length and weight of individual fish were measured at 0 , $15,30,45$, and 60 days of the experiment. 25 fish at the beginning and 3 fish per tank (12 fish per treatment) were sampled at the end of the experiment to analyzed carcass composition. 3fish per tank were also selected at the end of the trial to evaluate condition factor.

\section{Experimental diets}

Proximate composition of ingredients used for the preparation of treatment diets is shown in (Table 1). Ingredients such as shrimp head meal, fish meal, tapioca, sunflower oil, vitamin and mineral mixture (Valaenza Pharmaceuticals Private Limited) and cod liver oil (Sanofi India Limited, Sanofi Consumer Healthcare Division) were used for feed formulation (Table 2). Five isonitrogenous treatment diets with $40 \%$ protein level were prepared viz. $\mathrm{T} 1=$ control (100\% fish meal as primary protein source; zero $\%$ shrimp head meal $),$ T2 $=(75 \%$ of fish meal and 25\% shrimp head meal $), \mathrm{T} 3=(50 \%$ of fish meal and 50\% shrimp head meal), T4 = (25\% of fish meal and $75 \%$ shrimp head meal) and $\mathrm{T} 5=(0 \%$ of fish meal and $100 \%$ shrimp head meal).

\section{Diet preparation and feeding}

Shrimp head was collected from Star Fish Meal Plant, Veraval, Gujarat, India. It was sun-dried for 3 days before it was ground. All the ingredients were mixed together, made a dough and cooked in an autoclave for 10 minutes. The $\mathrm{n}$ it was pelleted into $1 \mathrm{~mm}$ size pellets, and dried in a mechanical drier. The dry feed was stored in airtight plastic bottles. The feed was provided at the rate of $10 \%$ of body weight initially, and after 10 days fishes 
were fed ad libitum three times daily (09.00, 13.00 and 18.00 hours) till the end of the experiment.

\section{Chemical analysis}

Proximate composition was determined for feed ingredients, treatment diets, and whole fish by the standard methods (AOAC, 1995). The nitrogen content by Gerhardt semiautomated method, fat by Soxhlet apparatus, moisture by hot air oven $\left(100-105^{\circ} \mathrm{C}\right)$, ash by muffle furnace $\left(600^{\circ} \mathrm{C}\right)$. Nitrogen free extract was calculated by subtracting the protein, lipid, moisture, and ash from the total weight of the food (Table 2).

\section{Calculations}

The following calculations were made:

Length gain $(\%)=($ Final length - Initial length / Initial length) x 100

Weight gain $(\%)=[($ Final weight - Initial weight)/Initial weight] x 100

Feeding Rate, FR (\% Body weight/day) = [Dry feed intake/ $\{60$ days $(\mathrm{FBW}+\mathrm{IBW}) / 2\}] \mathrm{x}$ 100

Feed efficiency rate, $($ FER $)=$ Wet weight gain $(\mathrm{g}) /$ total amount of the feed consumed $(\mathrm{g})$

Protein efficiency ratio, $(\mathrm{PER})=$ Increment in body weight $(\mathrm{g}) /$ Protein intake $(\mathrm{g})$

Protein Productive Value $[\mathrm{PPV}(\%)]=[$ Body wet protein gain $(\mathrm{g}) /$ Protein intake $(\mathrm{g})] \mathrm{x} 100$

Protein growth rate $\left[\mathrm{PGR}\left(\% \mathrm{day}^{-1}\right]=\left[\left(\log _{\mathrm{e}}\right.\right.\right.$ final protein content $-\log _{\mathrm{e}}$ initial protein content)/days of feeding] x 100

Condition factor $(\mathrm{CF})=$ Weight of fish $(\mathrm{g}) /[\text { Length of fish }(\mathrm{cm})]^{3} \times 100$
Survival $(\%)=$ (No. of fish survived after rearing/No. of fish stocked) x 100

\section{Statistical analysis}

One way Analysis of Variance (ANOVA) and least significantly difference (LSD) (Snedecor and Cochran, 1968) was applied to test the level of significance amongst the treatments.

\section{Results and Discussion}

Table 3 shows the effects of different protein sources on fish performance. The growth curve is plotted to determine the average growth rate of tilapia fry during the experimental period (Fig. 1 and Fig. 2). Weight gain $(354.84 \pm 3.32)$ of fish fed with diet T3 $(50 \%)$ was found to be significantly $(\mathrm{p}<0.05)$ higher as compared to control and other treatment diets. Similarly, PER (1.64 \pm 0.02$)$, PPV (\%) (76.20 \pm 0.94$)$ and PGR $\left(\%\right.$ day $\left.^{-1}\right)(0.98 \pm 0.00)$ were found significantly $(\mathrm{p}<0.05)$ higher in the fish fed with diet T3. The lowest value of weight gain (202.33 \pm 4.46$)$, PER (1.03 \pm 0.02$)$, PPV (\%) $(42.46 \pm 1.00)$ and PGR $\left(\%\right.$ day $\left.^{-1}\right)(0.81 \pm 0.01)$ were obtained in fish fed with diet T5 (0\% fish meal: $100 \%$ of shrimp head meal). FER $(41.33 \pm 0.99)$ was significantly $(p<0.05)$ lower in the fish fed with diet $\mathrm{T} 1$ and higher $(65.67 \pm 0.81)$ in diet T3. The rate of fish survival ranged $100 \%(\mathrm{p}>0.05)$ in all the treatment groups. Significantly $(\mathrm{p}<0.05)$ higher feeding intake was observed in diet T3 (Fig. 3). When the quadratic regression analysis was used for estimating the optimum dietary SHM level for maximal weight gain and PER for tilapia fry, the regression equations used were $\mathrm{y}=-0.0632 x^{2}+6.3565 x$ $+205.51\left(\mathrm{R}^{2}=0.9894\right)($ Fig. 4$)$ and $\mathrm{y}=$ $-0.0003 x^{2}+0.0263 x+1.0449\left(\mathrm{R}^{2}=0.978\right)$ (Fig. 5). All diets were well accepted by Nile tilapia during the 60 days feeding trial. This was revealed by the food intake (FI) values in the present study. The FI decreased with the 
increasing of dietary SHM in treatment 4 and 5 and significant $(\mathrm{p}<0.05)$ differences in FI were found between the treatments (Figure 3).

This was in agreement with previous studies on red porgy (Garcia et al., 2010; Kalinowski et al., 2007). However, Yi et al., (2014) found that the supplementation of SHM in the diets of large yellow croaker (Larimichthys croceus) reflected with a higher feed intake in fish fed with control diet in contrast to those fed with SHM diets.

Table.1 Proximate composition of ingredients used for preparation of treatment diets

\begin{tabular}{|c|c|c|c|c|c|c|}
\hline Ingredients & Moisture & $\begin{array}{c}\text { Dry } \\
\text { matter }\end{array}$ & Ash & Protein & $\begin{array}{l}\text { Ether } \\
\text { extract }\end{array}$ & $\begin{array}{c}\text { Nitrogen free } \\
\text { extract }\end{array}$ \\
\hline Fish meal $^{1}$ & 8.42 & 91.58 & 23.93 & 44.01 & 8.41 & 15.23 \\
\hline Shrimp head meal & 6.52 & 93.48 & 27.84 & 43.12 & 6.45 & 16.07 \\
\hline Wheat flour $^{2}$ & 5.74 & 94.26 & 1.92 & 11.46 & 2.68 & 78.20 \\
\hline Wheat bran ${ }^{2}$ & 6.62 & 93.38 & 3.88 & 14.83 & 2.95 & 71.72 \\
\hline Rice flour ${ }^{2}$ & 5.45 & 94.55 & 1.76 & 11.75 & 0.97 & 80.07 \\
\hline
\end{tabular}

${ }^{1}$ Star fish meal plant, Veraval, Gujarat, India

${ }^{2}$ Local market, Veraval, Gujarat, India

Table.2 The formulation of control and treatment diets

\begin{tabular}{|c|c|c|c|c|c|}
\hline \multirow[t]{2}{*}{ Ingredients } & \multicolumn{5}{|c|}{ Diets } \\
\hline & T1 (Control) & $\mathrm{T} 2$ & T3 & $\mathrm{T} 4$ & T5 \\
\hline Shrimp head meal (43.12 CP) & 0 & 23 & 46 & 69 & 92 \\
\hline Fish meal (44.01 CP) & 92 & 69 & 46 & 23 & 0 \\
\hline Wheat bran (14.83 CP) & 1 & 1 & 1 & 1 & 1 \\
\hline Rice Flour (11.75 CP) & 1 & 1 & 1 & 1 & 1 \\
\hline Wheat Flour (11.46 CP) & 1 & 1 & 1 & 1 & 1 \\
\hline Tapioca & 1 & 1 & 1 & 1 & 1 \\
\hline Sun flower oil ${ }^{1}$ & 1 & 1 & 1 & 1 & 1 \\
\hline Fish Oil ${ }^{2}$ & 2 & 2 & 2 & 2 & 2 \\
\hline Vitamin Mixture $^{3}$ & 1 & 1 & 1 & 1 & 1 \\
\hline Total & 100 & 100 & 100 & 100 & 100 \\
\hline \multicolumn{6}{|c|}{ Proximate analysis (determined on dry matter basis) } \\
\hline Crude protein (CP) (\%) & 40.48 & 40.25 & 40.02 & 39.79 & 39.56 \\
\hline Ether extract $(\%)$ & 10.07 & 9.84 & 9.78 & 9.53 & 9.28 \\
\hline $\operatorname{Ash}(\%)$ & 21.94 & 22.62 & 22.94 & 23.28 & 23.37 \\
\hline Moisture (\%) & 7.57 & 7.75 & 7.97 & 8.44 & 9.52 \\
\hline Nitrogen free extract $(\%)$ & 19.94 & 19.54 & 19.29 & 18.96 & 18.27 \\
\hline \multicolumn{6}{|c|}{$\begin{array}{l}{ }^{1} \text { Gemini sunflower oil } \\
{ }^{2} \text { Seven sea cods } \\
{ }^{3} \text { Vitamin and mineral mixture/Kg premix: Vitamin A-7,00,000IU, VitaminD3-70,000IU, Vitamin E-250 mg, } \\
\text { Nicotinamide-1000 mg, Cobalt-150mg, Copper-1200mg, Iodine-25g, Iron-1500 mg, Magnesium-6000 mg, } \\
\text { Manganese-1500 mg, Potassium-100mg, Sodium- 5.9mg, Sulphur-0.72\%, Zinc-9600 mg, Calcium-25.5\%, } \\
\text { Phosphorus-12.75\%. }\end{array}$} \\
\hline
\end{tabular}


Table.3 Growth, food conversion ratio, protein efficiency ratio and survival of $O$. niloticus fed the test diets for 60 days

\begin{tabular}{|c|c|c|c|c|c|}
\hline \multirow[t]{2}{*}{ Parameters } & \multicolumn{5}{|c|}{ Treatment } \\
\hline & $\mathrm{T}_{1}$ (Control) & $\mathrm{T}_{2}$ & $\mathrm{~T}_{3}$ & $\mathrm{~T}_{4}$ & $\mathrm{~T}_{5}$ \\
\hline $\begin{array}{l}\text { Length gain } \\
(\%)\end{array}$ & $55.12 \pm 4.78^{c}$ & $74.75 \pm 1.33^{b}$ & $82.97 \pm 1.49^{\mathrm{a}}$ & $72.49 \pm 0.63^{b}$ & $55.29 \pm 0.59^{c}$ \\
\hline $\begin{array}{l}\text { Weight gain } \\
(\%)\end{array}$ & $202.33 \pm 4.46^{\mathrm{c}}$ & $334.75 \pm 2.31^{b}$ & $354.84 \pm 3.32^{\mathrm{a}}$ & $330.74 \pm 1.37^{b}$ & $208.68 \pm 1.25^{c}$ \\
\hline $\begin{array}{l}\text { FR (\% bw day } \\
\left.1^{-}\right)\end{array}$ & $4.06 \pm 0.05^{\mathrm{a}}$ & $3.28 \pm 0.02^{b}$ & $3.25 \pm 0.03^{b}$ & $3.27 \pm 0.01^{b}$ & $4.07 \pm 0.02^{\mathrm{a}}$ \\
\hline FE $(\%)$ & $41.33 \pm 0.99^{c}$ & $63.60 \pm 0.53^{b}$ & $65.67 \pm 0.81^{\mathrm{a}}$ & $63.47 \pm 0.35^{\mathrm{b}}$ & $41.80 \pm 0.37^{c}$ \\
\hline PER & $1.03 \pm 0.02^{c}$ & $1.59 \pm 0.01^{b}$ & $1.64 \pm 0.02^{\mathrm{a}}$ & $1.58 \pm 0.01^{\mathrm{b}}$ & $1.05 \pm 0.01^{\mathrm{c}}$ \\
\hline PPV (\%) & $42.46 \pm 1.00^{\mathrm{e}}$ & $69.43 \pm 0.57^{b}$ & $76.20 \pm 0.94^{\mathrm{a}}$ & $60.74 \pm 0.33^{c}$ & $50.16 \pm 0.45^{d}$ \\
\hline PGR (\% day $\left.{ }^{-1}\right)$ & $0.81 \pm 0.01^{\mathrm{c}}$ & $0.97 \pm 0.00^{\mathrm{b}}$ & $0.98 \pm 0.00^{\mathrm{a}}$ & $0.96 \pm 0.00^{\mathrm{b}}$ & $0.82 \pm 0.00^{c}$ \\
\hline $\mathrm{CF}$ & $12.3 \pm 1.02^{\mathrm{a}}$ & $11.79 \pm 0.01^{\mathrm{ad}}$ & $10.81 \pm 0.29^{\mathrm{bcd}}$ & $12.2 \pm 0.07^{\mathrm{ab}}$ & $12.12 \pm 0.03^{\mathrm{ac}}$ \\
\hline Survival (\%) & $100 \pm 0.00$ & $100 \pm 0.00$ & $100 \pm 0.00$ & $100 \pm 0.00$ & $100 \pm 0.00$ \\
\hline
\end{tabular}

"Mean \pm SE within a row followed by with different superscripts are significantly different $(\mathrm{p}<0.05)$ from each other. FR- Feeding Rate (\% Body weight day-1), FE- Feed Efficiency, PER- Protein Efficiency Ratio, PPV- Protein Productive Value (\%), PGR- Protein growth rate $\left(\%\right.$ day $\left.^{-1}\right)$, CF- Condition Factor

Table.4 Proximate analysis of fish carcass (Dry weight basis)

\begin{tabular}{|c|c|c|c|c|c|}
\hline Parameters & T1 (Control) & T2 & T3 & T4 & T5 \\
\hline Crude protein & $40.82 \pm 0.71$ & $40.73 \pm 1.02$ & $40.60 \pm 0.53$ & $40.47 \pm 1.57$ & $40.35 \pm 0.61$ \\
\hline Ethe r extract & $14.93 \pm 0.72$ & $14.87 \pm 0.54$ & $14.73 \pm 0.26$ & $14.67 \pm 0.76$ & $14.58 \pm 0.74$ \\
\hline Ash & $21.95 \pm 1.02$ & $22.17 \pm 1.54$ & $22.26 \pm 0.63$ & $22.45 \pm 0.62$ & $22.56 \pm 1.24$ \\
\hline Moisture & $20.57 \pm 0.94$ & $20.61 \pm 0.73$ & $20.74 \pm 0.97$ & $20.85 \pm 0.34$ & $20.93 \pm 0.04$ \\
\hline $\begin{array}{c}\text { Nitrogen free } \\
\text { extract }\end{array}$ & $1.73 \pm 0.03$ & $1.62 \pm 0.04$ & $1.67 \pm 0.03$ & $1.56 \pm 0.03$ & $1.58 \pm 0.04$ \\
\hline
\end{tabular}

${ }^{*}$ Mean \pm SE within a row followed by with different superscripts are significantly $(\mathrm{p}<0.05)$ different from each other

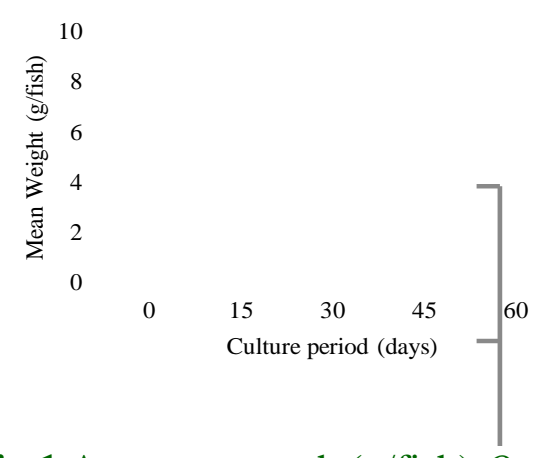

Fig.1 Average growth (g/fish) O. niloticus fed different experimental diets for 60 days

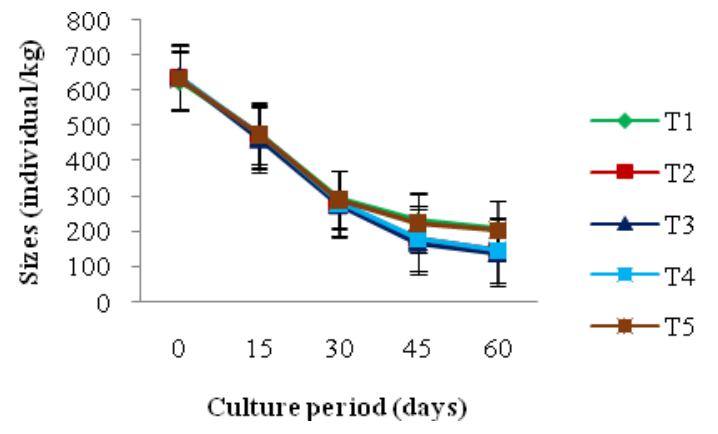

Fig.2 Average growth (individual $/ \mathrm{kg}$ ) of $O$. niloticus fed different experimental diets for 60 days 


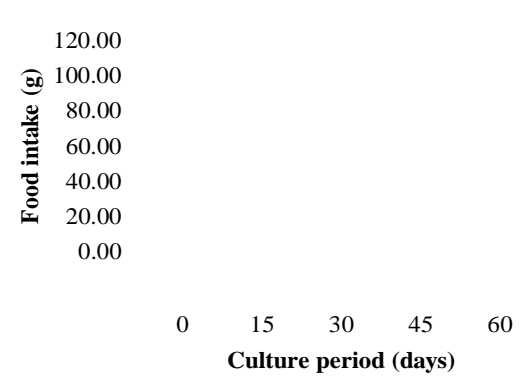

Fig.3 Average food intake of $O$. niloticus fed different experimental diets for 60 days

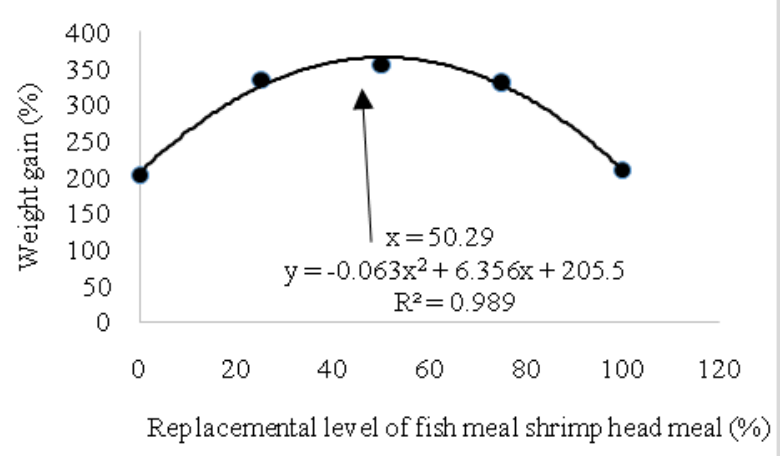

Fig.4 The relationship between weight gain and dietary SHM protein replacement level in tilapia fry for 60 days

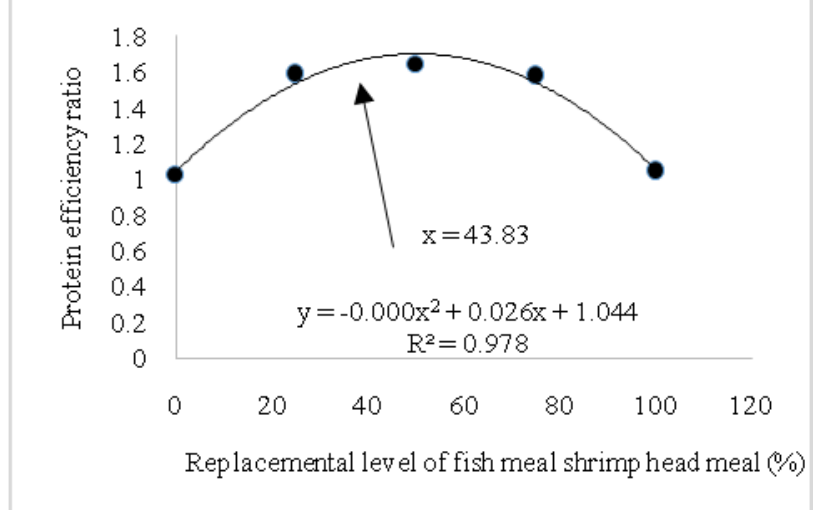

Fig.5 The relationship between protein efficiency ratio and dietary SHM protein replacement level in tilapia fry for 60 days

In the present study, significantly higher weight gain was found in $\mathrm{T} 2$ diet containing $75 \%$ fish meal and 25\% SHM. This was in disagreement with reports on tilapia $(O$. niloticus) (Nwanna and Daramola, 2000) and stripped catfish (Pangasianodon hypophthalmus) (Da et al., 2012). In the present study, the poor growth and feed utilization of diet T4 and T5 may be due to the low digestibility and utilization of SHM, because significant lower PER and FER were observed in the dietT5 compared to T3 group (Table 3). Likewise, high supplementation of SHM and the low inclusion of fish meal may diminish the feed palatability. Usually, the reduction in diet palatability results in a fall in feed intake, which could in turn cause decrease growth (Aragao et al., 2003; Kissil et al., 2000). In the present study, significantly the higher FER was obtained in T3 diet containing 50\% fish meal and50\% SHM. However, Fall et al., (2012) reported that the supplementation of $0 \%$ shrimp shell meal (control) in the diet showed significant higher FER in hybrid tilapia (Oreochromis niloticusx Oreochromis aureus). The present study demonstrated that $25 \%$ of SHM included in diets for Nile tilapia indicated significantly $(\mathrm{p}<0.05)$ higher PER compared to other diets. This was in disagreement with the study of Rachmansyah and Ahmad (2004) in which the $\mathrm{y}$ found higher PER without significant ( $p>0.05)$ difference in juvenile Humpback Grouper (Cromileptes altivelis) when fed with $10 \%$ SHM. Secondary curve equation according to the regression analysis of PER and weight gain against dietary fish meal protein replacement levels with SHM 
recommended that the optimum replacement level of dietary SHM for maximum weight gain and PER was in between 43.83 to $50.29 \%$.

Chemical analysis (moisture, protein, lipid and ash content) at the end of a feeding trial is often used to determine the effect of feed on fish composition (Table 4). Garcia-Romero et al., (2014a) found significantly $(\mathrm{p}<0.05)$ higher crude ether extract in red porgy fed with $20 \%$ marine crab (Chaceon affinis) meal diet compared to the $10 \%$ marine crab meal diet. Alternatively, Garcia-Romero et al., (2014b) could not find significant in the ether extract of red porgy supplemented with $20 \%$ marine spider crab meal.

The differences in these results could be due to the differences in the crustacean species used in the diet and/or the supplementation level. A greater proportion of chitin, chitosan, and ash in the diets may diminish the total digestible nutrients intake, which could be the clarification as to the whole-body ether extract reduction that seems in fish fed with a higher supplementation of SHM. Chitin and chitosan can inhibit the absorption of dietary lipids and lipid soluble vitamins by forming gels in the intestinal tract (Koide, 1998; Liao et al., 2007).

The present study has revealed that shrimp head meal is a potential protein source and can be used to substitute fish meal up to $50 \%$ in the diets of tilapia (O. niloticus). As the shrimp head meal is locally and easily available at much cheaper prices than fish meal, there is a good scope for preparing tilapia feed using shrimp head meal as a source for partial replacement of fish meal protein. Second-degree polynomial regression analysis on PER and weight gain indicated the appropriate supplement of SHM in the diet of Nile tilapia fry should be between 43.83 and $50.29 \%$ of diet.

\section{References}

Aragao, C., Conceiccao, L.E.C., Dias, J., Marques, A.C., Gomes, E. and Dinis, M.T.2003. Soy protein concentrate as a protein source for Senegalese sole (Solea senegalensis Kaup1858) diets: effects on growth and amino acid metabolism of post-larvae. Aquac. Res.34:1443-1452.

Da, C.T., Lundh, T. and Lindberg, J.E. 2012. Evaluation of local feed resources as alternatives to fish meal in terms of growth performance, feed utilization and biological indices of striped catfish (Pangasianodon hypophthalmus) fingerlings. Aquaculture.364-365:150156.

Deng, J., Zhang, X., Bi, B., Kong, L. and Kang, B. 2011. Dietary protein requirement of juvenile Asian red-tailed catfish (Hemibagrus wyckioides). Animal Feed Science and Technology. 170:231-238.

Fagbenro, O.A. 2004. Soybean meal replacement by roquette (Eruca sativa Miller) seed meal as protein feedstuff in diets for African catfish (Clarias gariepinus, Burchell1822) fingerlings. Aquaculture Research. 35:917-923.

Fall, A., Tseng, Y., Ndong, D. and Sheen, S. 2012. The effects of replacement of soybean meal by shrimp shell meal on the growth of hybrid tilapia (Oreochromis niloticus x Oreochromis aureus) reared under brackish water. International Journal of Fisheries and Aquaculture. 4(5): 85-91.

Fontainhas-Fernandes, A., Gomes, E., ReisHenriques, M.A. and Coimbra, J.1999. Replacement of fish meal by plant proteins in the diet of Nile tilapia: digestibility and growth performance. Aquaculture International.7:57-67.

Garcia, J.R., Kalinowski, C.T.H., Izquierdo, M.S.L. and Robaina, L.E.R. 2010. 
Marine and fresh water crab meals in diets for red porgy (Pagrus pagrus): effect on growth, fish composition and skin colour. Aquac. Res.41:1759-1769.

Garcia-Romero, J., Gines, R., Izquierdo, M. and Robaina, L.2014a. Marine and freshwater crabmeals in diets for red porgy (Pagrus pagrus): effect on fillet fatty acid profile and flesh quality parameters. Aquaculture. 420-421:23123

Garcia-Romero, J., Gines, R., Izquierdo, M.S., Haroun, R., Badilla, R., Robaina, L. 2014b. Effect of dietary substitution of fish meal for marine crab and echinoderm meals on growth performance, ammonia excretion, skin colour, and flesh quality and oxidation of red porgy (Pagrus pagrus). Aquaculture. 422-423:239-248.

Gatlin, D.M. 2010. Principles of fish nutrition. Southe rn Regional Aquculture Center. Pp. 1-8.

Glencross, B., Hien, T., Phuong, N., Cam and $\mathrm{Tu}, \mathrm{T} .22011$. A factorial approach to defining the energy and protein requirements of Tra catfish (Pangasianodon hypothalamus). Aquaculture Nutrition. 17: 396-405.

Hardy, R.W., Tacon, A.G.J. 2002. Fish meal historical uses, production trends and future outlook for sustainable supplies. In: Stickney RR (ed) Sustainable Aquaculture, New York, CABI. Pp. 413-414.

Hung, L.T., Suhenda, N., Slembrouck, J., Lazard, J. and Moreau, Y.2004. Comparison of dietary protein and energy utilization in three Asian catfishes (Pangasius bocourti, $P$. hypophthalmus and $P$. djambal). Aquaculture Nutrition. 10:317-326.

Hung, L.T., Suhenda, N., Slembrouck, J., Lazard, J., Moreau, Y. 2003. Comparison of starch utilization in fingerlings of two Asian catfishes from the Mekong River (Pangasius bocourti Sauvage, 1880, Pangasius hypophthalmus Sauvage, 1878). Aquaculture Nutrition. 9:215-222.

Kalinowski, C.T., Izquierdo, M.S., Schuchardt, D. and Robaina, L.E. 2007. Dietary supplementation time with shrimp shell meal on red porgy (Pagrus pagrus) skin colour and carotenoid concentration. Aquaculture. 272:451457.

Kissil, G.W., Lupatsch, I., Higgs, D.A., Hardy, R.W., 2000. Dietary substitution of soy and rapeseed protein concentrates for fish meal, and their effects on growth and nutrient utilization in gilthead sea bream Sparus aurata L. Aquac. Res. 31:595-601.

Koide, S.S. 1998. Chitin-chitosan: properties, benefits and risks. Nutr. Res.18:10911101.

Liao, F.H., Shieh, M.J. Chang, N.C. and Chien, Y.W. 2007. Chitosan supplementation lowers serum lipids and maintains normal calcium, magnesium, and iron status in hyperlipidemic patients. Nutr. Res. 27:146-151.

Liu, X., Wang, Y., Ji, W. 2011. Growth, feed utilization and body composition of Asian catfish (Pangasius hypophthalmus) fed at different dietary protein and lipid levels. Aquaculture Nutrition. 17: 578-584.

Meyers, S.P. 1986. Utilization of shrimp processing wastes. Info Fish Marketing Dig. 4(86): 18-19.

Miles, R.D., Chapman, F.A. 2012. The benefits of fish meal in aquaculture diets. Institute of Food and Agricultural Sciences, University of Florida, Florida. Pp. 1-3.

Nwanna, L.C., Daramola, J.A. 2000. Harnessing of shrimp head waste in Nigeria for low cost production of tilapia, Oreochromis niloticus (L.). In: 
Fitzsimmons, K., Filho, J.C. (eds.) Tilapia aquaculture in the 21 st Century. 5th Intl. symp. on Tilapia in Aquaculture, Rio de Janeiro, Brasil. Vol. 3-7, Pp 174-178.

Nyina-wamwiza, L., Wathe let, B., Kestemont, P. 2007. Potential of local agricultural byproductsfor the rearing of African catfish (Clarias gariepinus) in Rwanda: effects on growth, feed utilization and body composition. Aquaculture Research. 38: 206-214.

Phumee, P., Wei, W.Y., Ramachandran, S. and Hashim, R. 2011. Evaluation of soybean meal in the formulated diets for juvenile Pangasianodon hypophthalmus (Sauvage, 1878). Aquaculture Nutrition. 17:214-222.

Rachmansyah, A.L., Ahmad, T. 2004.The Use of Shrimp Head Meal as a Substitute to Fish Meal in Diets for Humpback Grouper (Cromileptes altivelis). In: Rimmer, M.A., McBride, S., Williams, K.C. (eds) Advances in Grouper Acquaculture, Canberra.

Snedecor, G.W., Cochran, W.G. 1968. Statistical Methods, $6^{\text {th }}$ edn., Oxford and IBH Pub. Co., New Delhi, 593p.

Srour, T.M. 2009. Fish waste and shrimp head silage as dietary protein sources for Nile tilapia, Oreochromis niloticus. Egyptian J. Anim. Prod. 46(1):69-84.

Sumi, S.M.2014. Suitability of ARO123 and UNH995 microsatellite Markers in the sex linkage study of Nile tilapia (Oreochromis niloticus L.). Department of fisheries biology and genetics, Bangladesh agricultural university, Mymensingh. Pp. 1-4.

The Marine Ingredients Organization (2015). Statistical yearbook 55th annual conference. Berlin, Germany.

Wanna, L.C., Balogun, A.M., Ajenifuja, Y.F., Enujiugha, V.N. 2004. Replacement of fish meal with chemically preserved shrimp head in the diets of African catfish, Clarias gariepinus. Food, Agriculture \& Environment. 2(1):79-83.

Yi, X., Xu, W., Zhou, H., Zhang, Y., Luo, Y., Zhang, W., Mai, K.2014. Effects of dietaryastaxanthin and xanthophylls on the growth and skin pigmentation of large yellow croaker Larimichthys croceus. Aquaculture. 433: 377-383.

\section{How to cite this article:}

Sanjay Singh Rathore and Sajid I. Yusufzai. 2018. Emerging Animal Protein Source to Replace Fish Meal in the Diets of Nile Tilapia (Oreochromis niloticus) Fry. Int.J.Curr.Microbiol.App.Sci. 7(05): 1227-1235. doi: https://doi.org/10.20546/ijcmas.2018.705.149 